\title{
The family of the child with special health care needs and their social relationships
}

\author{
A família da criança com necessidades especiais de saúde e suas relações sociais \\ La familia del niño con necesidades especiales de salud y sus relaciones sociales
}

\section{Rayssa Nascimento Vasconcellos' ORCID: 0000-0001-8822-9608 \\ Maria Helena do Nascimento Souza ORCID: 0000-0003-2230-3048 \\ Vanessa Medeiros da Nóbrega" ORCID: 0000-0002-2596-8259 \\ Neusa Collet" ORCID: 0000-0002-4795-0279}

'Universidade Federal do Rio de Janeiro. Rio de Janeiro, Rio de Janeiro, Brazil. "Universidade Federal da Paraíba. João Pessoa, Paraíba, Brazil.

How to cite this article: Vasconcellos RN, Souza MHN, Nóbrega VM, Collet N. The family of the child with special health care needs and their social relationships. Rev Bras Enferm. 2022;75(Suppl 2):e20210031. https://doi.org/10.1590/0034-7167-2021-0031

Corresponding author:

Rayssa Nascimento Vasconcellos E-mail: rayvasc322@gmail.com

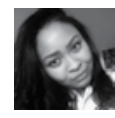

EDITOR IN CHIEF: Antonio José de Almeida Filho ASSOCIATE EDITOR: Maria Isabel Salamanca

Submission: 01-18-2021

Approval: $12-07-2021$

\begin{abstract}
Objectives: to identify aspects that can influence the types of bonds developed in the social support network of family members of children with special health care needs. Methods: qualitative research conducted through interviews with 15 family members/guardians in the city of Rio de Janeiro, from January to February 2020. Sanicola's theoretical-methodological framework and Bardin's thematic analysis technique were used. Results: social distancing, lack of responsibility for coordinating care, lack of supplies and lack of individualized care were weaknesses found in the families' social relationships. However, the bonds were strengthened by the relationship of familiarity and availability of professionals in the care of children with special health needs. Final Considerations: understanding the configuration of primary and secondary social networks and the types of support offered can improve the care of children and strengthen bonds that provide security for families.

Descriptors: Social Networking; Social Support; Child; Family; Nursing Care.
\end{abstract}

\section{RESUMO}

Objetivos: identificar aspectos que podem influenciar os tipos de vínculos estabelecidos na rede de apoio social de familiares de crianças com necessidades especiais de saúde. Métodos: pesquisa qualitativa, realizada mediante entrevista com 15 familiares/responsáveis residentes no município do Rio de Janeiro, no período de janeiro a fevereiro de 2020. Utilizaram-se o referencial teórico-metodológico de Sanicola e a técnica de análise temática de Bardin. Resultados: o distanciamento social, a desresponsabilização pela coordenação do cuidado, a falta de insumos e de um acolhimento singular evidenciaram as fragilidades nas relações sociais familiares. No entanto, os vínculos foram fortalecidos pela relação de familiaridade e disponibilidade dos profissionais no cuidado à criança com uma necessidade especial de saúde. Considerações Finais: compreender a configuração das redes sociais primária e secundária e os tipos de apoios ofertados pode contribuir para a melhoria do cuidado às crianças e fortalecer laços que geram segurança às famílias.

Descritores: Rede Social; Apoio Social; Criança; Família; Cuidados de Enfermagem.

\section{RESUMEN}

Objetivos: identificar aspectos que puedan influenciar los vínculos establecidos en la red de apoyo social de familiares de niños con necesidades especiales de salud. Métodos: se trata de una investigación cualitativa, llevada a cabo con entrevista de 15 familiares/responsables residentes en el municipio de Río de Janeiro, entre enero y febrero de 2020. Se utilizó el marco teórico y metodológico de Sanicola y la técnica de análisis temático de Bardin. Resultados: el distanciamiento social, la irresponsabilidad en la coordinación de los cuidados, la falta de insumos y de una acogida singular pusieron de manifiesto las debilidades de las relaciones sociales familiares. Sin embargo, los vínculos se vieron reforzados por la relación de confianza y disponibilidad de los profesionales en el cuidado del niño con necesidad sanitaria especial. Consideraciones Finales: comprender la configuración de las redes sociales primarias y secundarias y los tipos de apoyo que ofrecen puede contribuir para mejorar el cuidado de los niños y reforzar los vínculos que generan seguridad para las familias.

Descriptores: Red Social; Apoyo Social; Niño; Familia; Atención de Enfermería. 


\section{INTRODUCTION}

Children with special health care needs (CSHCN) are those who live with limitation, disability or an emotional, psychological or developmental condition. These children are more susceptible to complications and constantly require specialized health care ${ }^{(1-2)}$.

Data from a National Survey of Children's Health conducted in the United States showed that between 2018 and 2019, 18.9\% of children had some special health care need ${ }^{(3)}$. In Brazil, although there is no national epidemiological survey on the prevalence of these children, almost a quarter of Brazilian children have a chronic health condition ${ }^{(4)}$, making them $\mathrm{CSHCN}$. Compounding this problem, $47.8 \%$ of children aged 0 to 14 are in poverty and live in families with an income of about a quarter of the minimum wage per capita ${ }^{(5)}$. Studies show that chronic health problems in childhood associated with social vulnerability are a serious public health problem and a great challenge for the family and for the health professionals who provide them with care ${ }^{(6-10)}$.

The daily lives of families of children with special health care needs can be marked by several difficulties, such as: frequent hospitalizations, concerns, social isolation, family burden, conflicts, reduction of family income, anxiety, fear and changes in the household routine. This situation becomes even more critical when the family does not have the support of their social network for childcare ${ }^{(9,11)}$.

In recent decades, studies have considered the influence of social support as a positive factor in coping with adversities in the daily lives of families living with some type of chronic disorder. Therefore, it is important to investigate the social support strategies of these families, as social support can enable care and protection of children and their families, reducing feelings of distress, fear and insecurity in childcare ${ }^{(2,8-9)}$.

However, in addition to the support strategies used by families of CSHCN, it is important to know the factors that can influence the bonds established in their social network, contribute to the strengthening of this network and, consequently, increase the support of these families throughout life $e^{(1-4,12-13)}$.

Despite of the advances and public policies focusing on children with chronic conditions in Brazil, there are gaps in the knowledge about the family context of children with special health care needs and the influence of their social relationships on treatment adherence, rehabilitation and quality of life. Furthermore, a study found that social support contributes to the acceptance of the chronic condition, adaptation to the new reality, resilience and family coping ${ }^{(14)}$. In this context, it is relevant to think of strategies to favor the development and strengthening of bonds between families of CSHCN and their social support network. Given the above, we ask: what has motivated the bonds of the families of CSHCN in their support networks?

\section{OBJECTIVES}

To identify aspects that can influence the types of bonds established in the social support network of family members of children with special health care needs.

\section{METHODS}

\section{Ethical aspects}

The research followed the ethical precepts established in Resolution number 466/2012 of the National Health Council and was approved by the Research Ethics Committee. The participants signed the Informed Consent Term (TCLE).

\section{Theoretical and methodological framework}

Data were analyzed in light of the concept of social network and support proposed by Sanicola ${ }^{(15)}$. The social network is a set of bonds, harmonic or not, established between its members. It can be primary, when composed of family members, friends, colleagues or neighbors; and secondary, expressed by the individual's relationship with professionals from nongovernmental organizations (NGOs), workplaces and public and private institutions of social assistance, health, education, religiosity or solidarity.

Social support, on the other hand, refers to the type of positive support that members of the social network offer, whether material, financial, emotional and/or psychological ${ }^{(15)}$. In addition, the bonds established with the members of the network can be classified as strong, normal, fragile, conflictual or broken ${ }^{(15)}$.

\section{Study type}

This is a descriptive study with a qualitative approach, based on the theoretical and methodological framework of the social network ${ }^{(15)}$. The recommendations of the Consolidated criteria for Reporting Qualitative research (COREQ) ${ }^{(16)}$ were followed to increase the methodological rigor of the study.

\section{Study setting}

The study was carried out in a Municipal Rehabilitation Center in the city of Rio de Janeiro.

\section{Study participants}

The participants were family members of children with special needs selected for convenience during the period in which they were receiving care in the Rehabilitation Center.

Family members over 18 years of age, who declared themselves responsible for children with special health care needs and who attended the Rehabilitation Center were included. Parents with psychiatric disorders that hindered their understanding of the instrument and participation in the interview were excluded.

A total of 30 children who were registered for follow-up by the staff of the Rehabilitation Center at the time of data collection, but fifteen did not participate in the survey due to absence in the consultations. According to the coordination of the Center, the reasons for the absences were: school holidays, poor financial situation of parents or guardians and difficult transportation to the Rehabilitation Center. 


\section{Data collection and organization}

The semi-structured interviews were conducted on prescheduled days, from January to February 2020, according to the demand for assistance to the children in the Rehabilitation Center. They were carried out individually in an environment with privacy, and conducted by one of the researchers, an undergraduate nursing student trained and skilled in qualitative research.

Each interview lasted an average of 30 minutes and was recorded on an electronic device. In addition to characterization data, the semi-structured script contained the following guiding questions:Tell me which people are present in your life at this stage when you are living with this child who has special health care needs; - What kind of bond do you have with them? - Did you ever need help, or did you have any difficulties taking care of the child? Who did you count on? - What kind of support do you receive or have received from these people? The interviews ended when all the guardians who attended the consultations during the data collection period were interviewed. Participants were identified with the letter " $F$ " for Family, followed by Arabic numerals according to the order in which the interviews were carried out:"F1","F2", "F3","F4" and so on.

\section{Data analysis}

The interviews were transcribed in full and analyzed according to the Thematic Content Analysis technique proposed by Bardin ${ }^{(17)}$, which aims to cut, aggregate and enumerating the text according to the speech fragments, highlighting units of meaning, so that they can be regrouped according to their respective categories and themes ${ }^{(17)}$. From this perspective, two categories emerged, namely: I) Primary social network and II) Secondary social network.

\section{RESULTS}

The participants of this study were 15 family members of CSHCN seen in a Rehabilitation Center in a city in the state of Rio de Janeiro, of which 12 were mothers, two were grandmothers and one was the aunt of the child. As for the level of education, four had completed elementary school, seven had completed high school and four had completed higher education. Only six reported having a job. The average family income was 2.3 minimum wages and, considering the number of dependents on the income, the average per capita income was 0.92 minimum wages.

As for the children, 12 were male and three female. The age ranged from one to seven years, and the diagnoses were: seven had Autistic Spectrum Disorder (F1, F2, F4, F6, F7, F8, F13), two had Down Syndrome (F9, F11), two had a cognitive deficit (F10, F14), one had a motor deficit (F15), one had cognitive and motor deficits (F5), one had cerebral palsy (F12) and one had microcephaly and cerebral palsy (F3).

The analysis of the configuration of the social network of the participants, who were the parents or guardians of the children, showed that the primary social network was composed of family members, friends and neighbors, and most types of bonds established between them were normal or strong. The secondary social network was composed of several health institutions (basic units, clinics, rehabilitation centers or hospitals), schools, NGOs and the Church. Most participants reported having a normal or conflictual bond with the people in these institutions. It is worth noting that the bonds established with members of the secondary network were identified as fragile or broken (Chart 1).

Chart 1 - Members of the primary and secondary social networks and type of bond reported by family members of children with special health care needs, Rio de Janeiro, Rio de Janeiro, Brazil, 2020

\begin{tabular}{|c|c|c|c|c|}
\hline \multirow{2}{*}{$\begin{array}{l}\text { Family } \\
\text { member }\end{array}$} & \multicolumn{2}{|l|}{ Primary social network } & \multicolumn{2}{|l|}{ Secondary social network } \\
\hline & Member & $\begin{array}{l}\text { Type of bond } \\
\text { reported }\end{array}$ & Institution & $\begin{array}{l}\text { Type of bond } \\
\text { reported }\end{array}$ \\
\hline $\mathrm{F} 1$ & $\begin{array}{l}\text { Mother, father, brother, uncles, } \\
\text { cousins, brother, friend, neighbor }\end{array}$ & $\begin{array}{l}\text { Strong } \\
\text { Normal }\end{array}$ & $\begin{array}{l}\text { Basic Health Unit, Rehabilitation Center, Speech } \\
\text { Therapist, School, Church, Municipal Social Development } \\
\text { Department }\end{array}$ & $\begin{array}{l}\text { Normal } \\
\text { Strong } \\
\text { Broken }\end{array}$ \\
\hline $\mathrm{F} 2$ & $\begin{array}{l}\text { Father, mother, friends, colleague, } \\
\text { neighbor, uncles and cousins }\end{array}$ & Normal & $\begin{array}{l}\text { Basic Health Unit, Rehabilitation Center, Public Hospital, } \\
\text { School, Church }\end{array}$ & $\begin{array}{l}\text { Normal } \\
\text { Fragile } \\
\text { Conflictual }\end{array}$ \\
\hline F3 & $\begin{array}{l}\text { Father, mother, grandparents, } \\
\text { uncles, cousins, friends, neighbor }\end{array}$ & $\begin{array}{l}\text { Normal } \\
\text { Strong }\end{array}$ & $\begin{array}{l}\text { Basic Health Unit, Rehabilitation Center, Public Hospital, } \\
\text { School, Church }\end{array}$ & Normal \\
\hline F4 & $\begin{array}{l}\text { Mother, father, sisters, } \\
\text { grandparents, friends and aunt }\end{array}$ & $\begin{array}{l}\text { Conflictual } \\
\text { Strong } \\
\text { Normal }\end{array}$ & $\begin{array}{l}\text { Basic Health Unit, Association of Parents and Friends of } \\
\text { Exceptional Children (APAE), Carpool group, Church }\end{array}$ & Normal \\
\hline F5 & $\begin{array}{l}\text { Mother, father, aunt, siblings, } \\
\text { grandmother, great-grandmother, } \\
\text { friends }\end{array}$ & $\begin{array}{l}\text { Normal } \\
\text { Strong }\end{array}$ & $\begin{array}{l}\text { Basic Health Unit, Workplace, Rehabilitation Center, } \\
\text { Public Hospital, School }\end{array}$ & $\begin{array}{l}\text { Conflictual } \\
\text { Normal }\end{array}$ \\
\hline F6 & $\begin{array}{l}\text { Mother, father, brother, } \\
\text { grandparents, aunt, cousin, friends } \\
\text { and colleagues }\end{array}$ & $\begin{array}{l}\text { Strong } \\
\text { Normal }\end{array}$ & $\begin{array}{l}\text { Basic Health Unit, Rehabilitation Center, Private doctors } \\
\text { (Speech Therapist, Psychiatrist, Pediatrician, Homeopath, } \\
\text { Social Assistance), Child and Youth Psychosocial Care } \\
\text { Center (CAPSI), Integrated Agreed Program(PPI), Day } \\
\text { Care, Spiritist Center }\end{array}$ & $\begin{array}{l}\text { Broken } \\
\text { Normal } \\
\text { Fragile } \\
\text { Strong }\end{array}$ \\
\hline
\end{tabular}




\begin{tabular}{|c|c|c|c|c|}
\hline \multirow{2}{*}{$\begin{array}{l}\text { Family } \\
\text { member }\end{array}$} & \multicolumn{2}{|l|}{ Primary social network } & \multicolumn{2}{|l|}{ Secondary social network } \\
\hline & Member & $\begin{array}{l}\text { Type of bond } \\
\text { reported }\end{array}$ & Institution & $\begin{array}{l}\text { Type of bond } \\
\text { reported }\end{array}$ \\
\hline F7 & $\begin{array}{l}\text { Mother, father, cousins, great- } \\
\text { grandmother, uncles, friends, } \\
\text { neighbors }\end{array}$ & $\begin{array}{l}\text { Strong } \\
\text { Normal } \\
\text { Fragile }\end{array}$ & $\begin{array}{l}\text { Basic Health Unit, Public Hospital, Municipal Hospital, } \\
\text { Rehabilitation Center, Public Polyclinic, Maternity, Mundo } \\
\text { Nosso Educational Center (CENOM), Church, School }\end{array}$ & $\begin{array}{l}\text { Broken } \\
\text { Normal } \\
\text { Strong }\end{array}$ \\
\hline F8 & $\begin{array}{l}\text { Mother, father, aunts and } \\
\text { grandmother }\end{array}$ & Normal & $\begin{array}{l}\text { Basic Health Unit, Rehabilitation Center, Mundo Nosso } \\
\text { Educational Center (CENOM), School, Public Hospital, } \\
\text { Social Assistance (Riocard) }\end{array}$ & $\begin{array}{l}\text { Conflictual } \\
\text { Normal }\end{array}$ \\
\hline F9 & $\begin{array}{l}\text { Mother, father, uncles, } \\
\text { grandparents, friends }\end{array}$ & $\begin{array}{l}\text { Strong } \\
\text { Normal }\end{array}$ & $\begin{array}{l}\text { Basic Health Unit, Hospitais Públicos, Rehabilitation } \\
\text { Center, Maternity, Benefit }\end{array}$ & $\begin{array}{l}\text { Normal } \\
\text { Conflictual }\end{array}$ \\
\hline F10 & $\begin{array}{l}\text { Mother, father, great-uncles, } \\
\text { grandparents, aunts, friends }\end{array}$ & Normal & $\begin{array}{l}\text { Basic Health Unit, Rehabilitation Center, Public Hospital, } \\
\text { Maternity, Catholic Church, Evangelical Church }\end{array}$ & $\begin{array}{l}\text { Broken } \\
\text { Normal }\end{array}$ \\
\hline F11 & $\begin{array}{l}\text { Mother, father, siblings, neighbor, } \\
\text { grandparents, uncles, cousins }\end{array}$ & $\begin{array}{l}\text { Normal } \\
\text { Strong }\end{array}$ & $\begin{array}{l}\text { Basic Health Unit, Rehabilitation Center Private Hospital, } \\
\text { Church }\end{array}$ & $\begin{array}{l}\text { Strong } \\
\text { Normal }\end{array}$ \\
\hline $\mathrm{F} 12$ & $\begin{array}{l}\text { Mother, father, grandmother, } \\
\text { friends }\end{array}$ & $\begin{array}{l}\text { Normal } \\
\text { Fragile }\end{array}$ & $\begin{array}{l}\text { Basic Health Unit, Private Hospital, Public Hospital, } \\
\text { Rehabilitation Center, Social Assistance (Rio card) }\end{array}$ & Normal \\
\hline F13 & $\begin{array}{l}\text { Mother, father, grandparents, } \\
\text { aunts, great-aunt, neighbor }\end{array}$ & Normal & $\begin{array}{l}\text { Basic Health Unit, Rehabilitation Center, Maternity, Private } \\
\text { Hospital }\end{array}$ & $\begin{array}{l}\text { Normal } \\
\text { Strong }\end{array}$ \\
\hline F14 & $\begin{array}{l}\text { Mother, father, siblings, aunts, } \\
\text { neighbors, grandparents }\end{array}$ & $\begin{array}{l}\text { Normal } \\
\text { Strong }\end{array}$ & $\begin{array}{l}\text { Basic Health Unit, Rehabilitation Center Public Hospital, } \\
\text { Child and Youth Psychosocial Care Center (CAPSI), } \\
\text { Evangelical Church }\end{array}$ & $\begin{array}{l}\text { Conflictual } \\
\text { Normal }\end{array}$ \\
\hline F15 & $\begin{array}{l}\text { Mother, father, sisters friends, } \\
\text { grandparents, uncles }\end{array}$ & Normal & $\begin{array}{l}\text { Basic Health Unit, Rehabilitation Center Maternity, } \\
\text { Spiritist Center, Carpool group }\end{array}$ & $\begin{array}{l}\text { Fragile } \\
\text { Normal } \\
\text { Strong }\end{array}$ \\
\hline
\end{tabular}

Two thematic categories emerged from the analysis: primary social network and secondary social network, both with subcategories as shown below.

\section{Category I: Primary social network}

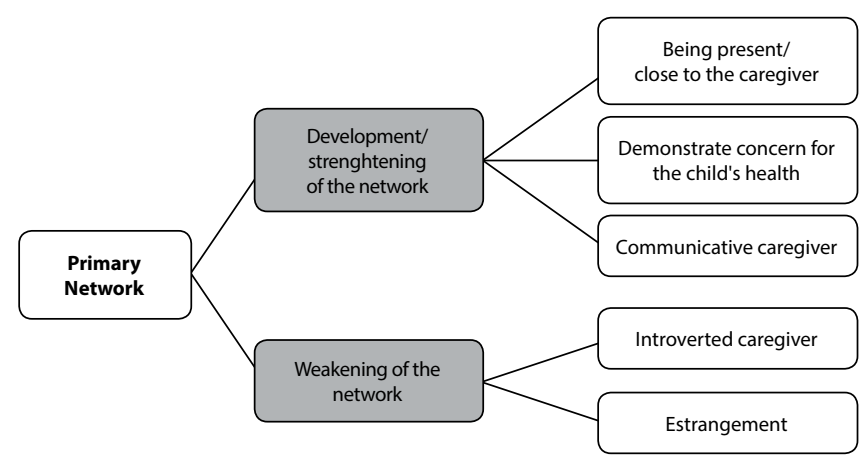

Figure 1 - Categories and themes identified in the analysis of the primary network of the participants

Being present or close to the caregivers, whether physically, by phone call or digital media, contributes to their psychological or emotional support and gives them strength to face adversity. This help was perceived since birth, in the diagnosis of the disease and in daily care.

[...] from the moment I told them [family] about the diagnosis of " $M$ ", I felt and saw that my mother [the child's grandmother] was always present. (F11)

[...] I receive psychological support from my family, mainly from my mother, she is always there talking to me. (F15)
When the child's mother goes through an emergency, she refers to her husband/their child's father as a source of security, support, and financial help.

She was born prematurely and was in fetal distress [...] I was feeling bad [...] my husband was the one who stayed with me. (F1)

[...] / can count on him [husband] for everything I need [...]. He gives me various types of support: physical, financial, psychological. (F3)

The availability of other family members and friends to help care for children with special health care needs is also an important aspect to minimize the caregiver's burden and strengthen the network.

When I needed help to go to the hospital, when I didn't know where it was, they [family members] took me. When I still didn't have his benefit, they helped me with food, milk, all that. (F1)

They [friends] treat him like a normal child, if I ask for something and they can do it, they'll find a way to help me, I know I can count on these friends, so I can come here [to the Rehabilitation Center]. (F9)

In addition to offering direct care to the child, demonstrating concern for their health can also strengthen the network, as in these moments the family is able to share their experiences and alleviate the suffering with the support received.

[...] everybody [from the Rehabilitation Center] asks how his situation is, if he is developing well, everyone has this interaction [...]. (F3) 
[...] when all that sinks in and people start worrying about his well-being, we get less overwhelmed. (F9)

Interacting in person or online with other mothers/caregivers who are at the Rehabilitation Center where the children are monitored and experience similar situations in daily care also brings them closer and strengthens the network.

Besides being always together [the mothers from the Rehabilitation Center], [...] we have a group on WhatsApp to help each other, because it's all new for all of us. (F13)

A communicative behavior of the caregiver favors the strengthening of the support network.

[...] I talk, sometimes I even help people to seek treatment, or talk to other people who are going through a similar, different or even worse situation [...]. If I need to talk to someone, sit down and talk, I just do it. (F3)

The opposite of this situation was also identified: the introspection of the caregiver weakens the social support network.

I don't usually expose what I feel, [...], I don't really like to expose everything in my life [...]. (F5)

Idon't have friends outside my house, only people from home. Where we live I dedicate my life for him, just at home, just relatives. (F8)

Another aspect that weakens the network is the estrangement of people, for geographical and personal reasons on the part of the caregiver, or because members of the network do not know how to deal with the child's health condition or as a result of the daily tasks.

[...] my family is from far away, I can't count on them, I'm from Ceará, they're all from there. (F7)

I tried to keep her more inside, not going out too much [...] / waited for her to grow a little more so I could go [to the Rehabilitation Center]. (F11)

[...] what I feel the most is the overload, my aunt helps me when she can, my mother helps me. Everyone tries to help, but in the rush of everyday life, everyone has their duties, jobs, activities. (F6)

In their contact with the secondary network, composed mainly of health and social care institutions, most participants showed dissatisfaction with the care received, weakening the social network.

Regarding the care received in the primary health care network, the critical points pointed out were the lack of priority in care, the feeling of abandonment due to the poor quality of care, the staff not taking responsibility for coordinating the care and monitoring the child, and the lack of medication for their children.

I don't even go to this family clinic, [...] sometimes I get there and they don't see us, it's very difficult. [...] When my doctor sees me, he pretends he has not, he never stopped by my house, neither he nor the community agent. (F7)

\section{Category II: Secondary network}

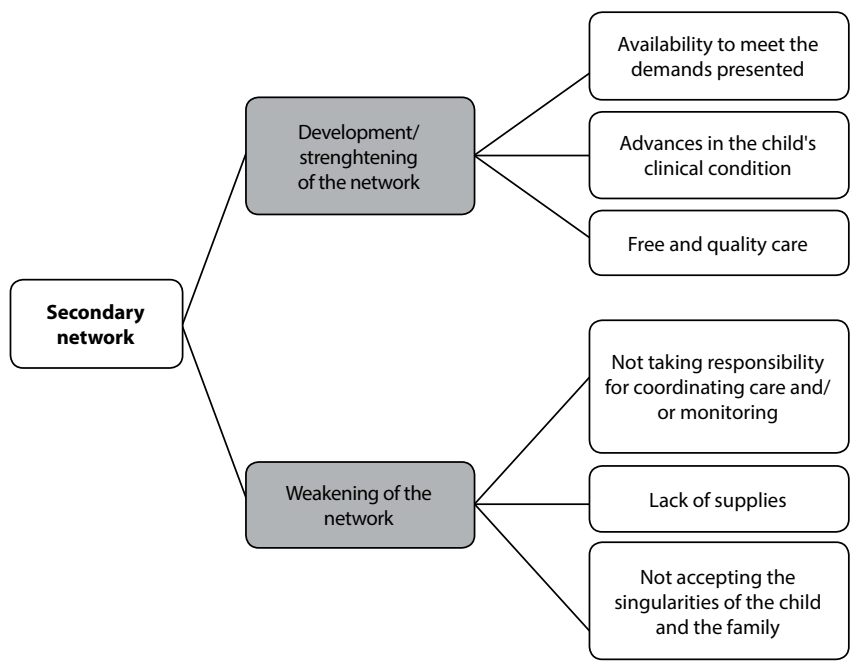

Figure 2 - Categories and themes identified in the analysis of the participants' secondary network

[...] in the Clinic it is difficult, because you get there with the sick person and you are only seen in the Clinic if the person has a high fever or is screaming. (F12)

[...] we don't receive good care, the medication my son needs is never available. I wait a long time for him to be seen, even though " $B$ " is special. I think he should be a priority, but there are several children in front of him, then it gets difficult. (F1)

In addition, caregivers reported a lack of professional qualification to deal with their children properly, as professionals delegated their work to interns, who did not have the skill to conduct the appointments and could not keep control of the children. This situation resulted in a broken bond.

The other place we went and did not stay was the CAPSI [Child and Youth Psychosocial Care Center], because we didn't really understand their objective. We took him, we stayed there for a while and we didn't see anything, [...] there were several interns, he [child] kept running everywhere and the interns just kept chasing him. (F8)

Gaps in communication resulting from the distance between the professional and the family, insufficient guidance and the challenges to find the diagnosis and favor the continuity of treatment in the home environment were aspects that made the families unsatisfied. This was due to the lack of recognition of the unique needs of the family.

Zero communication. [...] Then later, several exams that did not show anything. [...] I didn't even know what autism was, I just thought he was different, when she [professional] arrived there, she asked me a lot of questions and gave me the diagnosis of autism. (F4)

I thought we were going to see what was going on inside [the care room], but we stay kind of far away. I thought that we would go there, or they would teach us to do something at home, the exercises, motor training, speech, something for us to keep doing at home. (F13) 
At school, another part of the secondary social network, the lack of guarantee of the child's right to education and the lack of support in the classroom also led to dissatisfaction and weakened bonds.

The teacher treated him well, but preferred if he didn't go [to school], She didn't say it with those words, she just said that if he was crying it would be better if he didn't go. [...] Now, at the new school they say he will have an assistant [class assistant for support in the classroom] [...] but while they don't have one I'll have to stay there at the school, in the classroom with him like an assistant, for him to get used to it. (F7)

In contrast, rehabilitation services were identified as a source of support and a welcoming environment, strengthening the network. In these places, parents and children feel and they clarify the clinical aspects and notice the improvement in child development. At the Rehabilitation Center, contact with the multidisciplinary team provides strength and support to ensure the continuity of treatment, despite the impact of the diagnosis.

Here [at the Rehabilitation Center] they have a psychologist, we understand it a little more, I think that when you have a baby in your womb and you discover that he has Down Syndrome, you have to prepare. (F9)

The relationship with the team here is really strong, after he came here [Rehabilitation Center] he has improved a lot, a lot. He can associate things. (F6)

The availability of the different parts of the secondary network to meet the demands of the child and family gave them strength to overcome adversity and contributed to coping. Having support to access the services of the Health Care Network alleviated the burden of the family as they did not have to go to several different services.

She [speech therapist] was one of the people who gave us the most guidance on what to do, which direction to seek, even on how to deal with the issue of leaving the diapers, because as he doesn't talk, the day care center didn't want to do it. (F4)

$\mathrm{He}$ [son] loves the school, all the children know him, the teachers too. When he does something different, which is an achievement, they [teachers] tell the other teachers, the students clap for him. When he left the diaper, oh my God, they were happy because now he wasn't a baby anymore, he was a little boy. (F6)

I think that I have a much closer bond with the professionals at the Family Clinic. Today, as I couldn't make an appointment for her [the daughter] for this month, I spoke with the Agent [community] and she told me to go on Thursday. So I have a strong connection with them. (F13)

\section{DISCUSSION}

A greater social support for caregivers of CSHCN has been associated with a decrease in psychological distress among children and in the risk of stress, loneliness, depression and anxiety among caregivers ${ }^{(2)}$. In this sense, knowing the aspects that can strengthen or weaken the development of bonds in the social support network is essential to help the family to overcome the difficulties arising from the situation.

One of the strengthening aspects present both in the primary and secondary network refers to embracement. In the primary network, it is represented by being close to the caregiver, either in person or remotely, while in the secondary network it is represented by the availability to meet the demands of the family. This embracement can favor the direct care of the child and the care for the biopsychosocial needs of the family of a child with special health care needs.

In the primary social network, the members of the nuclear family, mainly the mother, husband and grandmother, support each other in childcare. These people are significant each other and can provide strength to face the demands of the CSHCN, helping to overcome difficulties arising after the diagnosis ${ }^{(1-2,8)}$. Friends and neighbors are also part of this primary social network $^{(13)}$, corroborating the findings of this study. These people help with the demands by offering instrumental support by providing direct care to the child, emotional support and positive social reinforcement, by showing concern with the experiences and opening up to listen to the family, alleviating their suffering.

However, the behavior of the caregiver can be either a strengthening or a weakening factor for the bond, as evidenced in this study. Their introspection is sometimes overcome by closeness and empathy of the other with their needs. The other, by having this welcoming attitude, favors the development of trust and, consequently, can enable an open dialogue and strengthen the bonds with the family ${ }^{(9)}$.

The secondary network was mainly represented by public or private health and education institutions. These findings corroborate a research carried out in the South Region of Brazil with adolescents with special health care needs, in which the family and healthcare institutions were pointed out as the main participants in the social network ${ }^{(13)}$.

In the secondary social network, humanized care favors the identification of the demands that are important to the family, so that they can be resolved in a proper and timely manner, solving the problem and bringing satisfaction. This close relationship promotes the development and strengthening of bonds between health professionals and the family ${ }^{(8)}$.

However, it was found that the bonds between the families of CSHCN and Primary Health Care (PHC) services were fragile, conflictual or broken. As the PHC is the preferred gateway to the health system, coordinator of the RAS and regulator of care, it should build comprehensive and lasting lines of care and a system of referral and counter-referral to ensure continuity of care $^{(7,18)}$.

However, several gaps in the application of these principles were identified and associated with different reasons, including the disarticulation of the RAS; lack of interprofessional relationships between professionals and services to meet the demands of CSHCN; difficulty maintaining the continuity of care, causing negative repercussions for clinical and social progress. This leads to the devaluation of care practices and lack of resolute care ${ }^{(19-20)}$. 
This way, the lack of supportive social relationships and the qualification of the multidisciplinary team to meet these demands makes dealing with the situation more exhausting and arduous. The actions of the team are not always proactive in face of the emotional, social and clinical demands of these children, generating disappointment and frustration for families and sometimes even driving them away from the health unit ${ }^{(7)}$.

Studies highlight that the moment of diagnosis causes affliction, fear and despair among mothers and family members due to its impact and the lack of preparation and prior knowledge ${ }^{(8-9)}$. When receiving the child's diagnosis, the family reports a feeling of apprehension, as the vocabulary of professionals is often technical and cold, raising doubts about the veracity of the information and leading them to search for other services ${ }^{(21)}$.

A powerful tool to overcome these problems is dialogue, which can strengthen bonds between the professional and the family. When the multidisciplinary team is accessible and willing to have an open and frank dialogue, the family starts to recognize it as a significant member of the support network. Thus, if professionals have an empathic posture based on the ethics of alterity, family members will seek them when they need information and support to cope with a given situation, which will strengthen this bond and, consequently, contribute for the expansion of the social support network ${ }^{(9,22)}$.

The need for family and institutional support is in line with the change in the daily life of a mother of a CSHCN. When this new condition arises, the dedication that was previously to the family as a whole starts to be focused on this child, who becomes the center of attention. In this context, the demands of daily life increase, overloading the mother and keeping them away from the perception of their own physical and mental health, which can also affect their self-esteem and their social life ${ }^{(23)}$. Overload and depression of parents make their children up to four times more likely to develop disorders such as anxiety and sleep disorders when compared to parents who do not have depression ${ }^{(24)}$

When the parents of CSHCN are unable to get the necessary rest, lack resilience or adequate social and community support, they get stressed, which negatively influences their actions. In this case, it can interfere in the way they treat this child and lead to abuse and neglect ${ }^{(2)}$.

In addition to emotional support, family support is also of great help for the mother/caregiver, especially when she lives in a situation of social vulnerability and needs to get to various health services to take the child to specialist doctors, nurses, psychologists, speech therapists, therapists, among others. Most of the time, these professionals do not work in the same environment, requiring more time, financial resources and family commutes to access the necessary services ${ }^{(6,18-20,25)}$.

The results of the present study are also in line with data from a study carried out with mothers/companions of hospitalized children, which found that the primary social network consists of strong family ties and the secondary network is basically characterized by institutional relationships related to treatment and health care ${ }^{(26)}$.

Studies show that the special needs of these children along with constant hospitalizations can affect the dynamics of social relationships and reduce contact with members of the primary network ${ }^{(2,10)}$. In addition to the estrangement caused by the need for hospitalizations, people may also drift away for geographic reasons, because they do not know how to deal with the child's health condition or due to daily tasks, weakening the bonds with the family.

In this sense, the health team can collaborate with the family by helping them to identify strategies to bring people closer and develop stronger ties to form a social network that provides support. Furthermore, developing strategies to implement public policies for this population can ensure timely access to actions and services and improve the quality of life of CSHCN and their families $^{(8)}$.

Another member of the secondary social network identified in this study was the school, which has not been offering adequate support to CSHCN and their families, having a negative impact on the development and strengthening of bonds.

A study points out that the school can strengthen the social support network by developing positive partnerships with parents, contributing to early and coordinated interventions with the health and family team and playing an important role supporting selfmanagement. School professionals can collaborate with families by monitoring changes in the child's health status, developing the treatment plan and ensuring adequate school support ${ }^{(2)}$.

\section{Limitations of the study}

a limitation of the present study is the fact that data were collected in a single rehabilitation unit and with a small number of participants. However, the results found may encourage further studies with the objective of broadening the discussion about the aspects involved in the social support relationships of children with special needs, not only in the context of rehabilitation centers but also in other services and levels of the health care network.

\section{Contributions to nursing and health}

given the above, nurses must be able to recognize the meaning and relevance of their insertion in social support networks of families of CSHCN, since the bonds and types of support offered by primary and secondary network are essential and have direct effects on treatment, adherence, and continuity of care.

It is extremely important that nursing professionals work together with the multidisciplinary team and all health and service networks, aiming at successful interprofessionalism. Thus, the following are essential: dialogue, active and qualified listening, empathy and expanded care, overcoming the technical-biomedical model with the objective of strengthening bonds of proximity and trust between all members of the social network.

\section{FINAL CONSIDERATIONS}

The primary social network of children with special health care needs was composed of family members, friends and neighbors, and the bonds established were normal or strong. In the relationships with members of the secondary social network, normal, conflictual, fragile or broken bonds were identified. 
These bonds were weakened by social distancing, lack of responsibility for coordinating care and the lack of individualized care. However, the bonds with members of the primary and secondary social network were strengthened by relationships of proximity, familiarity and availability of professionals who provide care to children with special health needs.

Thus, the use of the framework of the social network in the study of family members who live with CSHCN allowed understanding the influence of the relationship contexts of these family members on childcare. In addition, it represented an important support for the work of multidisciplinary teams aimed at promotion, protection and rehabilitation of children's health.

\section{FUNDING}

This study was financed in part by the Coordenação de Aperfeiçoamento de Pessoal de Nível Superior - Brasil (CAPES) - Finance Code 001 and the Scientific Initiation Scholarship Program of the Federal University of Rio de Janeiro (PiBIC/UFRJ).

\section{ERRATUM}

Article"The family of the child with special health care needs and their social relationships", with number of DOI: https://doi.org/10.1590/0034-7167-2021-0031, published in the journal Revista Brasileira de Enfermagem, 75(Suppl 2): e20210031, on page 8:

Include:

\section{FUNDING}

This study was financed in part by the Coordenação de Aperfeiçoamento de Pessoal de Nível Superior - Brasil (CAPES) - Finance Code 001 and the Scientific Initiation Scholarship Program of the Federal University of Rio de Janeiro (PiBIC/UFRJ).

\section{REFERENCES}

1. Cabral IE, Moraes JRMM. Family caregivers articulating the social network of a child with special health care needs. Rev Bras Enferm. 2015;68(6):769-76. https://doi.org/10.1590/0034-7167.2015680612i.

2. Mattson G, Kuo DZ. Psychosocial factors in children and youth with special health care needs and their families. Pediatrics. 2019;143(1):e20183171. https://doi.org/10.1542/peds.2018-3171

3. Child and Adolescent Health Measurement Initiative. National Survey of Children's Health 2018/19 [Internet]. 2019 [cited 2020 Nov 05]. Available from: https://www.childhealthdata.org/browse/survey/results?q=7713\&r=1

4. Neves ET, Okido ACC, Buboltz FL, Santos RP, Lima RAG. Accessibility of children with special health needs to the health care network. Rev Bras Enferm. 2019;72(Suppl-3):65-71. https://doi.org/10.1590/0034-7167-2017-0899

5. Instituto Brasileiro de Geografia e Estatística - IBGE. Indicadores Sociais Municipais: uma análise dos resultados do universo do censo demográfico 2010. IBGE; 28; 2011.

6. Neves ET, Cabral IE. A fragilidade clínica e a vulnerabilidade social das crianças com necessidades especiais de saúde. Rev Gaúcha Enferm [Internet]. 2008 [citado 2020 Aug 21];29(2):182-90. Available from: https://seer.ufrgs.br/RevistaGauchadeEnfermagem/article/view/5533/3150

7. Moreira MCN, Albernaz LV, Sá MRC, Correia RF, Tanabe RF. Recomendações para uma linha de cuidados para crianças e adolescentes com condições crônicas complexas de saúde. Cad Saúde Pública. 2017;33 (11):e00189516. https://doi.org/10.1590 / 0102-311x00189516

8. Reis KMN, Alves GV, Barbosa TA, Lomba GO, Braga PB. A vivência da família no cuidado domiciliar à criança com necessidades especiais de saúde. Cienc Enferm. 2017;23(1):45-55. https://doi.org/10.4067/S07179553201700010004

9. Machado AN, Nóbrega VM, Silva MEA, França DBL, Reichert APS, Collet N. Chronic disease in children and adolescents: professional-family bond for the promotion of social support. Rev Gaúcha Enferm. 2018;39:e2017-0290. https://doi.org/10.1590/19831447.2018.2017-0290

10. Souza MHN, Nóbrega VM, Collet N. Social network of children with cronic disease: knowledge and practice of nursing. Rev Bras Enferm. 2020;73(2):e20180371. https://doi.org/10.1590/0034-7167-2018-0371

11. Shahraki ZE, Efffatpanah M, Gray S, Radfar M, Rezaei M, Hekmat H, et al. A comparative study of psychiatric disorders among mothers of children with chronic diseases and mothers of healthy children. J App Pharm Sci [Internet]. 2017 [cited 2020 Feb 13];7(12):116-20. Available from: https://www.japsonline.com/abstract.php?article_id=2509

12. Silva MEA, Moura FM, Albuquerque TM, Reichert APS, Collet N. Network and social support in children with chronic diseases: understanding the child's perception. Texto Contexto Enferm. 2017;26(1):e6980015. https://doi.org/10.1590/0104-07072017006980015

13. Silveira A, Neves ET. The social network of adolescents who need special health care. Rev Bras Enferm. 2019;72(2):442-9. https://doi. org/10.1590/0034-7167-2018-0543

14. Easterlin MC, Berdahl CT, Rabizadeh S, Spiegel B, Agoratus L, Hoover C, et al. Child and family perspectives on adjustment to and coping with pediatric inflammatory bowel disease. J Pediatr Gastroenterol Nutr. 2020;71(1):e16-e27. https://doi.org/10.1097/ MPG.00000000000002693. 32142001

15. Sanicola, L. As dinâmicas da rede e o trabalho social. São Paulo: Veras; 2015. 
16. Tong A, Sainsbury P, Craig J. Consolidated criteria for reporting qualitative research (COREQ):a 32 -item checklist for interviews and focus groups. Int J Qual Health Care. 2007;19(6):349-57. https://doi.org/10.1093/intqhc/mzm04

17. Bardin L. Análise de conteúdo. São Paulo: Edições 70; 2011.

18. Duarte ED, Silva KL, Tavares TS, Nishimoto CLJ, Silva PM, Sena RR. Care of children with a chronic condition in primary care: challenges to the healthcare model. Texto Contexto Enferm. 2015;24(4):1009-17. https://doi.org/10.1590/0104-0707201500003040014

19. Mendes EV. A construção social da atenção primária à saúde. Brasília (DF): Conselho Nacional de Secretários de Saúde; 2015.

20. Silva KS, Santos AM, Carvalho JA, Kochergin CN, Almeida PF. Percepção de gestores e enfermeiros sobre a organização do fluxo assistencial na rede de serviços de saúde. RECIIS Rev Eletron Comun Inform Inov Saúde. 2017;11(2):1-12. https://doi.org/10.29397/reciis.v11i2.1226

21. Mickley KL, Burkhart PV, Sigler AN. Promoting normal development and self-efficacy in school-age children managing chronic conditions. Nurs Clin North Am. 2013;48(2):319-28. https://doi.org/10.1016/j.cnur.2013.01.009

22. Marcon SS, Dias BCC, Neves ETT, Marcheti MA, Lima RAG. (In)visibility of children with special health needs and their families in primary care. Rev Bras Enferm. 2020;73(Suppl 4):e20190071. https://doi.org/10.1590/0034-7167-2019-0071

23. Freitag VL, Milbrath VM, Motta MGC. The Mother-caregiver of child/teenager with Cerebral Palsy: Taking care of herself. Enferm glob [Internet]. 2018 [cited 2020 Aug 19];17(50):349-60. Available from: https://revistas.um.es/eglobal/article/view/265821/226381

24. Hamilton JL, Ladouceur CD, Silk JS, Franzen PL, Bylsma LM. Higher rates of sleep disturbance among offspring of parents with recurrent depression compared to offspring of nondepressed parents. J Pediatr Psychol. 2020;45(1):1-11. https://doi.org/10.1093/jpepsy/jsz079

25. Pinto MMPS, Coutinho SED, Collet N. Doença crônica na infância e a atenção dos serviços de saúde. Cienc Cuid Saúde [Internet]. 2016 [cited 2020 Aug 21];15(3):498-506. Available from: http://periodicos.uem.br/ojs/index.php/CiencCuidSaude/article/view/28575

26. Morais R, Souza T, Oliveira I, Moraes J. Structure of the social network of mothers/caregivers of hospitalized children. Cogitare Enferm. 2018;23(1):e50456. https://doi.org/10.5380/ce.v23i1.50456 